\title{
Cross-species transcriptomic approach reveals genes in hamster implantation sites
}

\author{
Wei Lei ${ }^{1, *}$, Jennifer Herington ${ }^{1,}{ }^{*}$, Cristi L Galindo ${ }^{2}$, Tianbing Ding ${ }^{3}$, Naoko Brown ${ }^{1}$, \\ Jeff Reese ${ }^{1}$ and Bibhash C Paria ${ }^{1}$ \\ ${ }^{1}$ Division of Neonatology, Department of Pediatrics, ${ }^{2}$ Division of Cardiovascular Medicine and ${ }^{3}$ Department of \\ Obstetrics and Gynecology, Vanderbilt University Medical Center, Nashville, Tennessee 37232, USA
}

Correspondence should be addressed to B C Paria; Email: bc.paria@vanderbilt.edu

*(W Lei and J Herington contributed equally to this work)

\begin{abstract}
The mouse model has greatly contributed to understanding molecular mechanisms involved in the regulation of progesterone $\left(P_{4}\right)$ plus estrogen (E)-dependent blastocyst implantation process. However, little is known about contributory molecular mechanisms of the $\mathbf{P}_{\mathbf{4}}$-only-dependent blastocyst implantation process that occurs in species such as hamsters, guineapigs, rabbits, pigs, rhesus monkeys, and perhaps humans. We used the hamster as a model of $\mathbf{P}_{\mathbf{4}}$-only-dependent blastocyst implantation and carried out cross-species microarray (CSM) analyses to reveal differentially expressed genes at the blastocyst implantation site (BIS), in order to advance the understanding of molecular mechanisms of implantation. Upregulation of 112 genes and downregulation of 77 genes at the BIS were identified using a mouse microarray platform, while use of the human microarray revealed 62 up- and 38 down-regulated genes at the BIS. Excitingly, a sizable number of genes ( 30 up- and 11 down-regulated genes) were identified as a shared pool by both CSMs. Real-time RT-PCR and in situ hybridization validated the expression patterns of several up- and down-regulated genes identified by both CSMs at the hamster and mouse BIS to demonstrate the merit of CSM findings across species, in addition to revealing genes specific to hamsters. Functional annotation analysis found that genes involved in the spliceosome, proteasome, and ubiquination pathways are enriched at the hamster BIS, while genes associated with tight junction, SAPK/JNK signaling, and PPAR $\alpha /$ RXR $\alpha$ signalings are repressed at the BIS. Overall, this study provides a pool of genes and evidence of their participation in up- and down-regulated cellular functions/pathways at the hamster BIS.
\end{abstract}

Reproduction (2014) 148 607-621

\section{Introduction}

The blastocyst implantation process in mammals is considered a remarkable evolutionary strategy for pregnancy success. A crucial component of this process includes the preparation of a receptive uterus under the control of maternal ovarian steroids (Paria et al. 1993). Studies have revealed that ovarian progesterone $\left(\mathrm{P}_{4}\right)$ is indispensable for the preparation of the uterus, while use of ovarian estrogen (E) strategies varies even within the rodent family members. For example, the uterus of mice, rats, and gerbils require exposure to both $\mathrm{P}_{4}$ and $\mathrm{E}$, whereas only ovarian $\mathrm{P}_{4}$ ensures preparation of the receptive uterus and blastocyst implantation in hamsters and guinea pigs (Reese et al. 2008). Other species such as rabbits, pigs, horses, rhesus monkeys, and possibly humans use a similar $\mathrm{P}_{4}$-dependent blastocyst implantation as found in hamsters and guinea pigs (Reese et al. 2008). Interestingly, studies have suggested that in some of these $\mathrm{P}_{4}$-dependent species such as rabbits, pigs, horses, hamsters, and humans, the blastocyst represents a potential alternative source of estrogen for implantation (reviewed in Reese et al. (2008)). Despite the striking commonality of maternal $\mathrm{P}_{4}$-dependent blastocyst implantation in hamsters and guinea pigs with the majority of other species, the use of hamsters or guinea pigs in identifying the molecules and/or molecular pathways that are enriched or suppressed at the blastocyst implantation site (BIS) compared with the interimplantation site (IIS) has been limited.

The uterus of mice, hamsters, and humans consists of two cellular compartments, the myometrium and endometrium. The endometrium is divided into two layers and consists of a simple columnar epithelium and an underlying stroma that contains glands made of epithelial cells, blood vessels, and bone marrow-derived immune cells, i.e. macrophages and lymphocytes. The bone-marrow-derived immune cells are also found in the myometrial compartment. Histological and ultrastructural studies of the early stages of implantation in 
the mouse, hamster, and human have demonstrated that trophoblast cells of the blastocyst make contact with uterine epithelial cells to initiate the process of implantation. While hamsters and mice exhibit an eccentric type of implantation, where the blastocyst lies within a uterine crypt, blastocyst implantation in humans is interstitial, where the blastocyst is completely embedded within the stromal tissue of the uterus. However, unlike the human in which polar trophoblast cells of the blastocyst initiate initial contact with endometrial uterine luminal cells, mural trophoblastic cells of blastocysts initiate contact with endometrial luminal epithelial cells in mice and hamsters (Lee \& DeMayo 2004, Reese et al. 2008). The luminal epithelial cells that are in contact with the blastocyst are larger than luminal epithelial cells of the IIS (WARD 1948). Ultrastructural studies have demonstrated that in contrast to mice and humans, where the epithelial cell surface becomes flattened and microvilli are replaced with pinopods (Aplin 1991), in hamsters epithelial microvilli persist during implantation (Parkening 1976a). Finally, while loss of mucin1 (a component of epithelial apical glycocalyx) occurs from the uterine epithelium at the time of implantation in mice (DeSouza et al. 1999), no evidence of reduction in mucin1 from apical surface of the uterine epithelium was observed in hamsters and humans (Hey et al. 1995, Reese et al. 2008). The uterine glands are few in number in the vicinity of the BIS as compared with IIS where the glands are more numerous. Contact between the trophoblast and luminal epithelial cells at the BIS initiates the transformation of stromal fibroblasts into decidual cells at the antimesometrial area. In hamsters and mice, decidualization is evident in the early phase of implantation. In contrast, the process of decidualization at the implantation site of humans is not evident until about 5 days after the embryo initiates contact with the stroma (Parkening 1976a,b, Aplin 1991). A dramatic redistribution of uterine macrophages takes place at the BIS of mice, such that macrophages egress from the implantation site. In this regard, macrophage distribution at the day 5 BIS of hamsters is unknown due to lack of such studies in this species.

Currently, the molecules involved in the initiation of the blastocyst implantation process have largely been derived using various approaches such as expression of individual genes, phenotypic characterization of genetically altered mice, and transcriptomics specified in studies carried out in mice. Despite these in-depth studies in mice, our understanding of the molecular regulation of the implantation process in humans is incomplete. Since several species from the rodent to primate showed ovarian $\mathrm{P}_{4}$-dependent blastocyst implantation, and the hamster and human showed certain striking similarities in early implantation events, the hamster could serve as an excellent rodent model for identifying common gene networks at the BIS of $\mathrm{P}_{4}$-dependent species or explaining differences in the molecular mechanisms between the $\mathrm{P}_{4^{-}}$and E-dependent blastocyst implantation processes and that perhaps might be more relevant in understanding the blastocyst implantation mechanisms in the human. However, this becomes difficult due to the unavailability of Syrian hamster microarray platforms and lack of transgenic technologies. The transcriptome of the Chinese hamster ovary $(\mathrm{CHO})$ cell line has been unveiled by next generation sequencing (Becker et al. 2011, Rupp et al. 2014). However, Schmucki et al. (2013) have demonstrated that the $\mathrm{CHO}$ transcriptome has limited value in identifying transcripts of lipid metabolism in the Syrian golden hamster liver, due to: i) different $\mathrm{CHO}$ cell lines containing different chromosome numbers owing to the effects of passaging and toxicant exposures, ii) extensive use of these cell lines in industries perhaps leading to genomic instability by chemical and radiation exposures (Xu et al. 2011, Hammond et al. 2012), and iii) Syrian hamster chromosome numbers (44) are twice the number of chromosomes (22) found in Chinese hamsters. Thus, our study explored the utility of using gene arrays of closely related mouse species and distantly related human species in the identification of differential gene expression patterns at the hamster BIS, keeping in mind that the information obtained from these CSM hybridizations may not identify important and/or rare transcripts due to insufficient gene sequence homology.

We propose an hypothesis that blastocyst implantation in the hamster results from the simultaneous change in the expression of a pool of genes that has functions pertinent to $\mathrm{P}_{4}$-dependent implantation. The results of our microarray analysis identified a set of upregulated and downregulated genes at the BIS as compared with their expression pattern at the IIS of hamsters. This pool of differentially expressed genes at the BIS of hamsters contains some previously identified genes involved in mouse implantation, as well as newly revealed additional genes, allowing us to discern relevant biological processes or pathways specific for the $\mathrm{P}_{4}$-dependent implantation site.

\section{Materials and methods}

\section{Reagents}

All reagents used in this study were obtained from SigmaAldrich unless otherwise specified.

\section{Animals}

Sexually-mature CD1 mice and Syrian Golden hamsters were purchased from Charles River Laboratories (Wilmington, MA, USA). The animals were maintained under controlled environmental conditions (room temp. $23 \pm 2{ }^{\circ} \mathrm{C}$; relative humidity (50-60\%); lighting conditions (12 h light/12 h dark, switched on/off at 0700/1900 h)) in our Institutional Animal Facility with 
unlimited access to food and water ad libitum. All experimental protocols using these animals were approved by the Vanderbilt University Animal Care and Use Committee.

\section{Preparation of animals for experiments and tissue collections}

Female hamsters that showed at least three consecutive 4-day estrous cycles were mated with fertile males overnight on the evening of proestrus. The next morning, the presence of sperm in the vaginal smear (estrus) indicated the first day of pregnancy. For mouse pregnancies, female and male mice were bred overnight and the presence of vaginal plug the following morning indicated day 1 of pregnancy (Zhang \& Paria 2006).

Uterine BISs and IISs from hamsters and mice on day 5 of pregnancy were identified after an i.v. injection of Chicago Blue B dye solution (Zhang \& Paria 2006). For microarray and real-time RT-PCR analysis, BISs were dissected from IISs and subjected to total RNA extraction in TRIzol reagent according to the manufacturer's instruction (Life Technologies; Reese et al. 2001, Lei et al. 2013). Three sets of RNA were isolated from three different animals.

\section{Microarray analysis}

Total RNA was collected as previously described (Reese et al. 2001) and then analyzed for purity and quantified. Three separate pairwise labeling, hybridization, and scanning analyses were carried out using GeneChip Mouse Expression 430A or GeneChip Human Genome U133A containing over 22000 probe sets, representing 14500 well-characterized mouse and human genes. All microarray data have been deposited at Gene Expression Omnibus (GEO) database (number: GSE59474). Raw.CEL files were uploaded into Partek Genomics Suite version 6.6 (Partek Incorporated, St Louis, $\mathrm{MO}$, USA) and processed using Robust Multi-chip Average (RMA) normalization (Bolstad et al. 2003, Irizarry et al. 2003). Following RMA normalization, Partek was used to perform pairwise comparisons of average group values and one-way ANOVA for analysis of BIS vs IIS. Principal component analysis (PCA) and hierarchal cluster analyses were conducted using Partek default settings. Only probes that resulted in a foldchange of at least 1.5 and $P<0.05$ without multiple hypothesis correction were considered as significantly altered genes. In order to compare differentially expressed gene lists obtained from mouse and human microarray platforms, human and mouse orthologs were searched using the bioDBnet website (http://biodbnet.abcc.ncifcrf.gov). Functional analyses of canonical pathways, and molecular and cellular functions that were altered by differentially expressed genes, was performed using Ingenuity Pathway Analysis (IPA) software, Redwood City, CA, USA. In addition, identification of overrepresented gene ontologies and KYOTO Encyclopedia of Genes and Genome (KEGG) pathways were performed using DAVID (http://david.abcc.ncifcrf.gov). Statistical analyses (including Benjamini \& Hochberg $(\mathrm{B}-\mathrm{H})$ correction for multiple hypothesis testing) were performed to identify relevant gene sets.

\section{Quantitative real-time RT-PCR}

To confirm the microarray results, representative genes were chosen at random for analysis using quantitative real-time RT-PCR. DNase-treated total RNAs $(1 \mu \mathrm{g})$ were reversed transcribed using oligo(dT) primers according to the manufacturer's instructions (Invitrogen). One microliter of the first strand was amplified in $25 \mu \mathrm{l}$ of total volume in an iCycler (Bio-Rad Laboratories, Inc.) using iQ SYBER Green Supermix; Bio-Rad). The following PCR protocol was used: $95^{\circ} \mathrm{C}$ for $3 \mathrm{~min}$ followed by 40 cycles of $95^{\circ} \mathrm{C}$ for $10 \mathrm{~s}$ and $60^{\circ} \mathrm{C}$ for $30 \mathrm{~s}$. All reactions were run in triplicates. The quantification was performed by the iQ 5 Standard Edition Optical System Version 2.0 (Lei et al. 2013). Data from real-time PCR analysis was normalized to hypoxanthine phosphoribosyltransferase (Hprt), a commonly used reference gene (Wang et al. 2011). Primer sequences for each gene are listed in Table 1.

\section{In situ hybridization using radioactive probes}

Plasmids bearing hamster or mouse cDNAs for Nppc and E2f8 were linearized and transcribed using appropriate RNA polymerases and labeled with ${ }^{35} \mathrm{~S}$ for in situ hybridizations. All labeled sense and antisense cRNA probes used for hybridizations had specific activities of approximately $\cong 2 \times 10^{9}$ d.p.m./ $\mu$ g. The protocol was followed as previously described by our group. Briefly, frozen uterine sections were mounted onto poly-L-lysine-coated slides and fixed in cold $4 \%$ paraformaldehyde solution in phosphate buffered saline (PBS) for 15 min on ice. After prehybridization, the sections were hybridized to ${ }^{35} \mathrm{~S}$-labeled antisense probes at $45{ }^{\circ} \mathrm{C}$ for $4 \mathrm{~h}$ in $50 \%$ formamide hybridization buffer. The sections were also hybridized with ${ }^{35} \mathrm{~S}$-labeled sense probes as a negative control. After hybridization and washing, the sections were incubated with RNase $\mathrm{A}$ at $37^{\circ} \mathrm{C}$ for $20 \mathrm{~min}$. RNase A resistant hybrids were detected by autoradiography using Kodak NTB-2 liquid emulsion (Eastman Kodak Company). The slides were then stained with hematoxylin and eosin (Wang et al. 2004, Lei et al. 2013).

\section{In situ hybridization with digoxigenin-labeled probes}

After linearization of plasmids bearing hamster Fst, Ran, and Ube2c cDNAs, digoxigenin-labeled antisense and sense cRNA probes were transcribed in vitro using the DIG RNA Labeling Kit (Roche Applied Science). In situ hybridization with digoxigenin-labeled probe was carried out as described previously (Lei et al. 2012). After fixing with 4\% paraformaldehyde solution in PBS, the frozen sections were hybridized with antisense or sense cRNA probes at $55^{\circ} \mathrm{C}$ for $16 \mathrm{~h}$ respectively. The sections were then washed and incubated in sheep antidigoxigenin-AP (1:5000; Roche Applied Science). The signal was visualized using diluted NBT/BCIP Stock Solution (Roche Applied Science). All of the sections were counterstained with $1 \%$ methyl green.

\section{Statistical analyses}

All experiments were repeated at least three times using different specimens. Statistically significant $(P<0.05)$ 
Table 1 Primers used for cloning and real-time RT-PCR.

\begin{tabular}{|c|c|c|c|c|}
\hline Gene name & $\begin{array}{l}\text { Sequence }\left(5^{\prime}-3^{\prime}\right) \\
\text { S, Sense; AS, Antisense }\end{array}$ & Accession no & Size (bp) & Application \\
\hline Actg2 & $\begin{array}{l}\text { S: CGCCCTAGACATCAGGGT } \\
\text { AS: TTCTGGTGCTACTCGAAGC }\end{array}$ & NM_009610 & 189 & Real-time RT-PCR \\
\hline Acvr2a & $\begin{array}{l}\text { S: CGGCATTGTTTTGCTACCTG } \\
\text { AS: TGTGTGACTTCCATCTCCGG }\end{array}$ & XM_005068951 & 200 & Real-time RT-PCR \\
\hline Atp $1 b 1$ & $\begin{array}{l}\text { S: ATGGGTTGTGTTGTGCTCC } \\
\text { AS: ACATGATGCCTCCAGAGA }\end{array}$ & XM_005071373 & 179 & Real-time RT-PCR \\
\hline $\mathrm{Cd} 24 \mathrm{a}$ & $\begin{array}{l}\text { S: ACCCACGCAGATTTACTGCA } \\
\text { AS: CGTTTCCTGGCCTGAGTCTC }\end{array}$ & NM_009846 & 191 & Real-time RT-PCR \\
\hline$E 2 f 8$ & $\begin{array}{l}\text { S: GAGAAATCCCAGCCGAGTC } \\
\text { AS: CATAAATCCGCCGACGTT }\end{array}$ & NM_001013368 & 157 & Real-time RT-PCR \\
\hline$E 2 f 8$ & $\begin{array}{l}\text { S: CAGTCAAGTGAACCCAGGAA } \\
\text { AS: CGGGTTGTAAGTAGATGGCA }\end{array}$ & XM_005083212 & 234 & Cloning \\
\hline Fst & $\begin{array}{l}\text { S: GCCTGTGGGATTTCAAGGTT } \\
\text { AS: CAGCTTCCTTCATGGCACAC }\end{array}$ & XM_005082770 & 135 & Real-time RT-PCR \\
\hline Fst & $\begin{array}{l}\text { S: TCTGCCAGTTCATGGAGGAC } \\
\text { AS: CACATTCGTTGCGGTAGGTT }\end{array}$ & XM_005082770 & 378 & Cloning \\
\hline Gadd45a & $\begin{array}{l}\text { S: CGTGCTAGTGACGAACCCAC } \\
\text { AS: ATTGAGATGCCATCACCGTT }\end{array}$ & XM_005076070 & 139 & Real-time RT-PCR \\
\hline Hnrnpd & $\begin{array}{l}\text { S: ATCCTATCACAGGGCGATCA } \\
\text { AS: GGCCCGTTTAGGATCAATGA }\end{array}$ & XM_005068122 & 125 & Real-time RT-PCR \\
\hline Hoxb6 & $\begin{array}{l}\text { S: AACAGTTCCTCTTTTGGGCC } \\
\text { AS: TCCTTTTTCCACTTCATGCG }\end{array}$ & XM_005075884 & 200 & Real-time RT-PCR \\
\hline Hprt & $\begin{array}{l}\text { S: CTTGCTGGTGAAAAGGACCTCTCGAAG } \\
\text { AS: TGAAGTACTCATTATAGTCAAGGGCAT }\end{array}$ & NM_013556 & 115 & Real-time RT-PCR \\
\hline Itm $2 b$ & $\begin{array}{l}\text { S: AGCTGCTCGCTACCAGACAA } \\
\text { AS: GATGGACGTGTTCAGAGGA }\end{array}$ & XM_005070971 & 197 & Real-time RT-PCR \\
\hline KIf9 & $\begin{array}{l}\text { S: CAGTCTGGAGAGTCCCGATG } \\
\text { AS: CCAGAGTGGAGGAGGGAGA }\end{array}$ & XM_005063225 & 139 & Real-time RT-PCR \\
\hline Lmna & $\begin{array}{l}\text { S: GCTGCACTGAGCACTGCTCT } \\
\text { AS: GGGTCTGCAGCCTGTTCTC }\end{array}$ & XM_005080125 & 163 & Real-time RT-PCR \\
\hline Nppc & $\begin{array}{l}\text { S: AGCGGTCTGGGATGTTAGTG } \\
\text { AS: CCTCCССTCCCCAAATAATA }\end{array}$ & NM_010933 & 202 & Real-time RT-PCR and cloning \\
\hline $\operatorname{Prd} 44$ & $\begin{array}{l}\text { S: CGGATCACTCCCTGCATCTA } \\
\text { AS: TGAGCTCCTTGAATTCTCCG }\end{array}$ & NM_016764 & 96 & Real-time RT-PCR \\
\hline Psmb3 & $\begin{array}{l}\text { S: GTGACCACGGACTTCCAGAA } \\
\text { AS: TACAGAAGGTTGGCCACCAT }\end{array}$ & XM_005139336 & 185 & Real-time RT-PCR \\
\hline Ran & $\begin{array}{l}\text { S: CTTGGAGTTTGTTGCCATGC } \\
\text { AS: TCCAGCTTCGCTTTCTCACA }\end{array}$ & XM_005079847 & 148 & Real-time RT-PCR \\
\hline Ran & $\begin{array}{l}\text { S: TTTGTTGCCATGCCTGCTC } \\
\text { AS: GCCCATTCATCTCCTTCAGC }\end{array}$ & XM_005079847 & 265 & Cloning \\
\hline Ube2c & $\begin{array}{l}\text { S: CCCCAGTGGCTACCCTTACA } \\
\text { AS: TGCGGACCACTTATCCTTGA }\end{array}$ & XR_219744 & 118 & Real-time RT_PCR \\
\hline Ube2c & $\begin{array}{l}\text { S: CCTGAATCAGACAACCTGTTC } \\
\text { AS: GCGGACCACTTATCCTTGAG }\end{array}$ & XR_219744 & 212 & Cloning \\
\hline Ypel3 & $\begin{array}{l}\text { S: ACAGGTCTTCATGCTGTCGC } \\
\text { AS: CCAGCCGTTGTCTTTGATCA }\end{array}$ & XM_005064410 & 150 & Real-time RT-PCR \\
\hline
\end{tabular}

differences in gene expression between each pair of experiments and the corresponding control samples were analyzed using Student's $t$-test.

\section{Results}

Overview of differentially expressed genes identified by the mouse and human gene chip microarray analyses

Exploratory analysis of the microarray data was performed, anticipating a clear and distinct pattern of gene expression at the hamster BIS due to the presence of the implanted blastocyst at this site compared with the IIS. PCA, on the entire probe sets within the mouse and human genome microarray platforms, provided a threedimensional view of global gene expression changes between independent samples. We found BISs were easily distinguishable from IISs for each of the three individual chip sets (Fig. 1A: blue dots vs red dots, respectively) for both of the microarray platforms. Despite variation in probe expression patterns among individual IIS observed in both microarrays, there was a clear separation from the BIS, which was very similar to one another across the genome.

Microarray comparison of transcriptomal profiles between BIS and IIS tissues showed that, among 2581 significantly expressed probes, 227 probes were differentially expressed with at least 1.5 -fold changes and confidence interval of $95 \%$ using the mouse microarray platform. Furthermore, use of the human array platform revealed a total of 1948 oligonucleotide probes that 
were significantly expressed, with 123 probes expressed at least 1.5 -fold difference $(P<0.05)$ between BIS and IIS. PCA performed using only the differentially expressed probes between BIS and IIS more successfully distinguished BIS and IIS samples (Fig. 1B) compared with PCA using the entire probe set (Fig. 1A).

In order to visually illustrate the pattern of the differentially expressed genes at the BIS and IIS, we constructed a heat map (representing the highest and lowest normalized signal values, black and grey respectively) using unsupervised hierarchical clustering (HC; Fig. 1C). HC showed that the 227 and 123

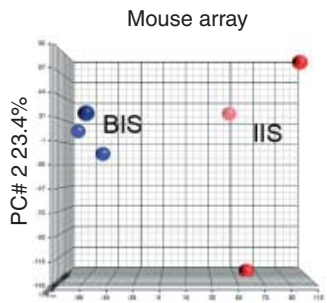

PC\# $318.2 \% \quad$ PC\# $128.1 \%$

B

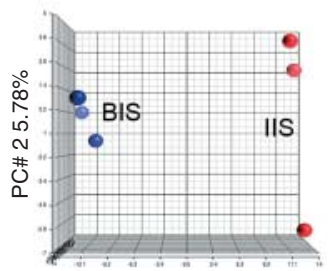

PC\# $32.93 \%$

C

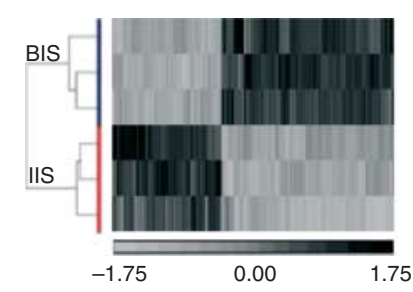

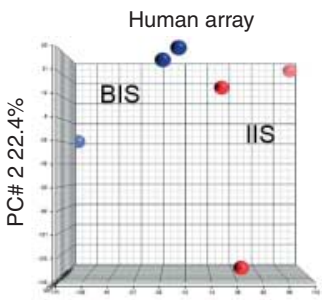
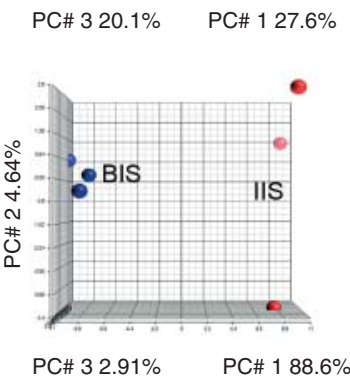

differentially expressed probes obtained by using mouse and human microarray platforms, respectively, were distinctly separated into BIS and IIS, as observed with the PCA (Fig. 1B), suggesting that these transcripts may have biological relevance to the blastocyst implantation process in hamsters.

In Affymetrix gene expression arrays, several genes are represented by more than one oligonucleotide probe from different regions of a same gene, in order to measure internal consistency of the data set. We found that 189 genes were represented by the 227 differentially expressed ( $\geq 1.5$-fold, $P<0.05$ ) mouse probes, and 100 genes were represented by the 123 differentially expressed human probes. The genes identified by multiple probe sets are listed in Table 2 .

Among the 189 differentially expressed genes identified by the mouse array, 112 (59\%) exhibited upregulation and 77 (41\%) exhibited downregulation at the BIS compared with the IIS (Fig. 1D). Of the 100 genes identified using the human array, $62(62 \%)$ were enriched in the BIS, whereas 38 (38\%) showed increased expression in the IIS (Fig. 1D). Remarkably, use of two different microarray platforms identified a sizable number of shared genes that were differentially expressed between BIS and IIS (Fig. 1D, official gene symbols provided); 30 of which were upregulated, while 11 were downregulated at the BIS. A complete list of all significantly differentially expressed genes obtained by both mouse and human microarray platforms is presented in supplemental Tables S1 and S2, see section on supplementary data given at the end of this article, while the top ten upregulated and downregulated genes in the BIS identified by the mouse and human array platforms can be found in Tables 3 and 4 respectively.

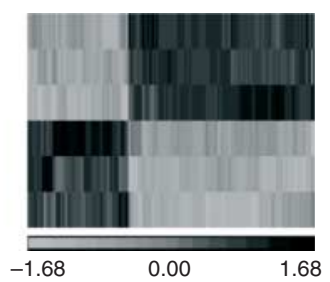

D Up-regulated genes (mouse vs human arrays)

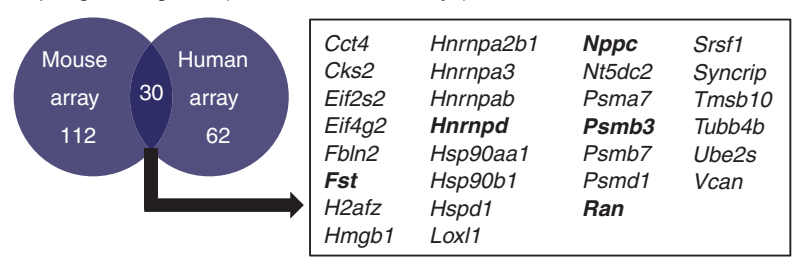

Down-regulated genes (mouse vs human arrays)

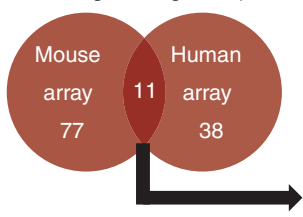

\begin{tabular}{|llll|}
\hline Actg2 & Itm2b & Pdgfra & Sat1 \\
Atp1b1 & Ivns1abp & Rbpms & Zfand6 \\
Hspb1 & Kdm6b & Rev3l & \\
\hline
\end{tabular}

Figure 1 Transcriptome of the hamster uterine blastocyst implantation site (BIS) is distinct from interimplantation site (IIS). (A) Principal component analysis (PCA) on the entire probe sets using mouse and human microarray platforms showed two distinct transcriptomes with clear separation of BIS samples (red) from IIS samples (blue). The effect of blastocyst implantation is visible in all three repeats. (B) PCA of differentiated genes (at least 1.5-fold $(P<0.05)$ ) demonstrated a clearer separation of the BIS (red) from the IIS (blue). (C) Hierarchical clustering (heat map) showed complete separation of differentially expressed 227 (mouse array: left panel) and 123 (human array: right panel) probes (at least 1.5 -fold, $P$ value $<0.05$ ) between the BIS and IIS. Values shown are log base 2, and black, light grey, and medium gray colors indicate the highest, lowest, and median normalized signal values respectively. Vertical dendrograms represent the three individual samples of hamster BIS and IIS. (D) Venn diagrams illustrate the overlap of gene transcripts that were at least 1.5 -fold $(P<0.05)$ different between hamster embryo implantation and interimplantation sites in both human and mouse Affymetrix cDNA microarrays. Official symbols of the shared genes are presented in the box and bolded gene transcripts represent those whose mRNA levels were validated using real-time RT-PCR analysis. 
Table 2 Differentially expressed genes identified by more than one probe.

\begin{tabular}{|c|c|c|c|c|}
\hline & \multicolumn{4}{|c|}{ Gene symbol/\# probes } \\
\hline & & & $\mathrm{Hu}$ & \\
\hline \multirow[t]{16}{*}{ Upregulated } & Cct3 & 4 & Eif4a1 & 2 \\
\hline & Chpt1 & 2 & Fst & 2 \\
\hline & Eif4a1 & 2 & Gspt1 & 2 \\
\hline & Eif5a & 2 & H2afz & 2 \\
\hline & Gapdh & 4 & Hnrnpd & 3 \\
\hline & Gja1 & 3 & Psme3 & 2 \\
\hline & Hnrnpab & 4 & Srsf1 & 3 \\
\hline & Hsp90аa1 & 2 & Syncrip & 2 \\
\hline & Hyou1 & 2 & Tuba1b & 5 \\
\hline & Ran & 3 & Tuba1c & 2 \\
\hline & $S d c 1$ & 2 & Tubb3 & 2 \\
\hline & Set & 2 & & \\
\hline & Srsf1 & 4 & & \\
\hline & Syncrip & 3 & & \\
\hline & Tmsb10 & 2 & & \\
\hline & Ywhag & 2 & & \\
\hline \multirow[t]{10}{*}{ Downregulated } & App & 2 & Atp1b1 & 2 \\
\hline & Atp1b1 & 2 & Fhl1 & 3 \\
\hline & Ccn/2 & 2 & & \\
\hline & $C d 24 a$ & 2 & & \\
\hline & Hspb1 & 2 & & \\
\hline & $\operatorname{lgk} c$ & 2 & & \\
\hline & Ogt & 2 & & \\
\hline & Sgms1 & 2 & & \\
\hline & Zbtb16 & 2 & & \\
\hline & Zfand6 & 2 & & \\
\hline
\end{tabular}

\section{Real-time RT-PCR and in situ hybridization validation of differentially expressed genes obtained from the mouse and human arrays}

A total of 18 protein coding genes, identified by either or both array platforms, were randomly selected for validation studies using real-time RT-PCR analysis (Fig. 2). The fold-change in expression obtained from the microarray analysis of these genes is presented in
Fig. 2A and D. In order to determine whether the differential expression pattern of these genes is specific to the hamster BIS, we chose to also examine their relative mRNA abundance at the BIS and IIS of the mouse. Of the 18 genes examined, 18 had mRNA levels that were significantly different between hamster BIS and IIS (Fig. 2B and E), while only 15 transcripts were differentially expressed between mouse BIS and IIS (Fig. 2C and F).

Of the shared gene transcripts examined, all five upregulated (Fst, Hnrnpd, Nppc, Psmb3, and Ran) and three downregulated (Actg2, Atp1b2, and Itm2b) showed significant $(P<0.05)$ differential expression at the BIS compared with the IIS of the hamsters (Fig. 2B). Among these eight genes, one upregulated (Psmb3) and one downregulated (Actg2) genes showed no significant $(P>0.05)$ change between the BIS and IIS of the mouse (Fig. 2C).

As previously stated, we randomly selected a total of 11 differentially expressed genes that were either identified only by the mouse or the human arrays (i.e., unshared; Fig. 2D) for validation by RT-PCR. All three upregulated genes (E2f8, Prdx4, and Ube2C) that were identified by the mouse array showed significant $(P<0.05)$ upregulation at the BIS compared with the IIS of hamsters (Fig. 2E). Among these three genes, E2f8 and Ube2c showed significant $(P<0.05)$ upregulation at the BIS of the mouse, while Prdx4 showed no significant $(P>0.05)$ differences between the BIS and IIS of mice (Fig. 2F). The protein coding Lmna gene that was identified by the human array showed significantly $(P<0.05)$ higher expression at the BIS compared with the IIS of both the hamster (Fig. 2E) and mouse (Fig. 2F). In agreement with the microarray results, all six downregulated protein coding genes (Acvr2a, Cd24a, Klf9,

Table 3 Top ten differentially expressed genes identified by mouse microarray platforms.

\begin{tabular}{|c|c|c|c|c|}
\hline Variation & Gene symbol & Gene name & Fold-change & $P$ value \\
\hline \multirow[t]{10}{*}{ Up } & Fst & Follistatin & 3.275 & $1.14 \times 10^{-3}$ \\
\hline & Cycs & Cytochrome $c$, somatic & 3.022 & $2.14 \times 10^{-4}$ \\
\hline & Hnrnpab & Heterogeneous nuclear ribonucleoprotein $\mathrm{A} / \mathrm{B}$ & 2.482 & $3.37 \times 10^{-6}$ \\
\hline & Hyou1 & Hypoxia upregulated 1 & 2.466 & $4.78 \times 10^{-3}$ \\
\hline & Manf & Mesencephalic astrocyte-derived neurotrophic factor & 2.233 & $1.13 \times 10^{-2}$ \\
\hline & Tmsb10 & Thymosin, beta 10 & 2.231 & $4.14 \times 10^{-3}$ \\
\hline & Nppc & Natriuretic peptide type C & 2.212 & $2.93 \times 10^{-4}$ \\
\hline & Nhp2 & NHP2 ribonucleoprotein & 2.200 & $3.00 \times 10^{-2}$ \\
\hline & Ada & Adenosine deaminase & 2.159 & $1.04 \times 10^{-2}$ \\
\hline & Lrrc59 & Leucine-rich repeat containing 59 & 2.190 & $7.80 \times 10^{-5}$ \\
\hline \multirow[t]{10}{*}{ Down } & Hspb1 & Heat shock protein 1 & -2.150 & $3.21 \times 10^{-3}$ \\
\hline & Ivns1abp & Influenza virus NS1A-binding protein & -2.150 & $6.81 \times 10^{-4}$ \\
\hline & $\lg k C$ & immunoglobulin kappa constant & -2.184 & $1.46 \times 10^{-2}$ \\
\hline & Tagln & Transgelin & -2.400 & $1.13 \times 10^{-2}$ \\
\hline & Sat1 & Spermidine/spermine N1-acetyl transferase 1 & -2.425 & $8.03 \times 10^{-3}$ \\
\hline & Itm2b & Integral membrane protein 2B & -2.556 & $2.58 \times 10^{-3}$ \\
\hline & Actg2 & Actin, gamma 2, smooth muscle, enteric & -3.337 & $2.01 \times 10^{-2}$ \\
\hline & Ogt & $\begin{array}{l}\text { O-linked } N \text {-acetylglucosamine (GlcNAc) transferase } \\
\text { (UDP- } N \text {-acetylglucosamine:polypeptide- }\end{array}$ & -3.393 & $3.08 \times 10^{-5}$ \\
\hline & $C d 24 a$ & CD24a antigen & -3.960 & $8.89 \times 10^{-6}$ \\
\hline & Atp1b1 & ATPase, $\mathrm{Na}+/ \mathrm{K}+$ transporting, beta 1 polypeptide & -4.002 & $8.31 \times 10^{-4}$ \\
\hline
\end{tabular}

Genes in bold font were confirmed to be differentially expressed using real-time RT-PCR analysis. 
Table 4 Top ten differentially expressed genes identified by human microarray platform.

\begin{tabular}{|c|c|c|c|c|}
\hline Variation & Gene symbol & Gene name & Fold-change & $P$ value \\
\hline \multirow[t]{10}{*}{ Up } & Fst & Follistatin & 3.891 & $4.74 \times 10^{-4}$ \\
\hline & Vcan & Versican & 2.762 & $1.26 \times 10^{-3}$ \\
\hline & Cks2 & CDC28 protein kinase regulatory subunit 2 & 2.551 & $6.12 \times 10^{-3}$ \\
\hline & Eif5a & Eukaryotic translation initiation factor $5 \mathrm{~A}$ & 2.532 & $3.99 \times 10^{-4}$ \\
\hline & Hsp90aa1 & Heat shock protein $90 \mathrm{kDa} \alpha$ (cytosolic), class A member 1 & 2.397 & $1.36 \times 10^{-3}$ \\
\hline & Ran & RAN, member RAS oncogene family & 2.359 & $3.05 \times 10^{-4}$ \\
\hline & H2afz & $\mathrm{H} 2 \mathrm{~A}$ histone family, member $\mathrm{Z}$ & 2.120 & $2.40 \times 10^{-3}$ \\
\hline & Loxl1 & Lysyl oxidase-like 1 & 2.119 & $5.74 \times 10^{-3}$ \\
\hline & Tuba1b & Tubulin, alpha $1 \mathrm{~b}$ & 2.077 & $1.83 \times 10^{-4}$ \\
\hline & Ndc1 & NDC1 transmembrane nucleoporin & 1.943 & $3.85 \times 10^{-3}$ \\
\hline \multirow[t]{10}{*}{ Down } & Ncoa2 & Nuclear receptor coactivator 2 & -1.787 & $2.72 \times 10^{-2}$ \\
\hline & Glul & Glutamate-ammonia ligase & -1.791 & $9.03 \times 10^{-3}$ \\
\hline & Bcl6 & B-cell CLL/lymphoma 6 & -1.896 & $5.51 \times 10^{-3}$ \\
\hline & Srsf7 & Serine/arginine-rich splicing factor 7 & -1.900 & $1.10 \times 10^{-3}$ \\
\hline & H2afy & $\mathrm{H} 2 \mathrm{~A}$ histone family, member $\mathrm{Y}$ & -1.904 & $2.46 \times 10^{-2}$ \\
\hline & Sat1 & Spermidine/spermine N1-acetyltransferase 1 & -1.985 & $1.32 \times 10^{-2}$ \\
\hline & Hspb1 & Heat shock 27 kDa protein 1 & -2.056 & $8.58 \times 10^{-3}$ \\
\hline & Hoxb6 & Homeobox B6 & -2.077 & $7.22 \times 10^{-3}$ \\
\hline & Fh/1 & Four and a half LIM domains 1 & -2.327 & $5.53 \times 10^{-3}$ \\
\hline & Atp1b1 & ATPase, $\mathrm{Na}+/ \mathrm{K}+$ transporting, beta 1 polypeptide & -4.074 & $1.85 \times 10^{-4}$ \\
\hline
\end{tabular}

Genes in bold font were confirmed to be differentially expressed using real-time RT-PCR analysis.

and Ypel3 identified by the mouse array; Gadd45a and Hoxb6 identified by the human array) at the BIS showed significantly $(P<0.05)$ decreased expression at the BIS compared with their expression patterns at the IIS of both species (Fig. 2E and F).

Next, we randomly selected five genes (Nppc, E2f8, Fst, Ran, and Ube2c), whose upregulation at the BIS was confirmed by real-time PCR analysis, for further analysis using in situ hybridization in order to examine their uterine site of localization and cell-type-specific expressions using longitudinal uterine sections containing BIS and ISS from hamsters and mice on day 5 of pregnancy. Nppc and E2f8 signals were localized in stromal cells, but not in the luminal epithelium, at the BISs of both the hamster and mouse (Fig. 3A). There was no expression of these genes in the cells of the implanted blastocyst. Nppc and E2f8 signals were not noted in any uterine cells away from the BIS. At the BIS of the hamster and mouse, Fst, Ran, and Ube2c mRNA expressions were found in the stromal cells away from the implanted blastocyst, but not in the subluminal stromal cells (Fig. 3B). Expression of mRNAs of Ran and Ube2c, but not Fst, was observed in the implanted blastocyst. Hybridization signals of these genes were not eminent in any uterine cell types of the IISs of either hamsters or mice (Fig. 3B). Together, results of real-time PCR and in situ hybridization showed correlative mRNA expression patterns of Nppc, E2f8, Fst, Ran, and Ube2C at the BIS.

\section{Functional classification of significantly upregulated and downregulated genes at the BIS}

During the microarray data analysis, we identified differential expression of multiple subtypes of the same gene, as well as multiple members of the same family of genes at the BIS, providing potential insights into enriched biological molecular and cellular functions or pathways involved in the blastocyst implantation process. In particular, several proteasomes (Psma7, Psmb3, Psmb7, Psmc4, Psmd1, and Psme3), tubulins (Tuba1b, Tuba1c, Tuba3a, Tubb3, Tubb4b, and Tubb5), eukaryotic translation initiation factors (Eif2s2, Eif4a1, Eif4g2, Eif5a, and Eif6), heat shock proteins (Hspd1, Hspa4, Hspa5, Hsp90aa1, and Hsp90b1), Hnrnpab (heterogeneous nuclear ribonucleoproteins, Hnrnpa2b1, Hnrnpa3, Hnrnpd, and Hnrnpu), and ubiquitins (Ube2c, Ube2k, Ube2m, and Ube2s) were identified as upregulated by either or both microarray platforms at the hamster BIS. Similarly, we also noticed that downregulated genes at the BIS, identified by using the mouse and human microarray platforms, also contained two families of genes that had more than three members: homeobox (Hoxa9, Dlx5, Hoxb6, Hoxb8, and Hox11as) and zincfinger proteins/domains (Zbtb16, Zfp36l2, Zfand6, and $Z c 3 h 11 a)$. The biological function was assessed by analyzing enriched molecular and cellular functions and canonical pathways using IPA software, as well as cluster analysis of gene ontology (biological processes) and KEGG pathways using the DAVID online tool.

\section{Molecular and cellular functions}

Ingenuity pathway analysis revealed that the enriched molecular and cellular functions at BIS, identified by both microarray platforms, included cellular growth and proliferation, RNA post-transcriptional modification, cellular development, protein synthesis, and cell death (Table 5). Similar molecular and cellular functions were enriched in IIS (Table 5), as the BIS, including cell death and survival, cellular growth and proliferation, cellular development, RNA post-transcriptional modification 

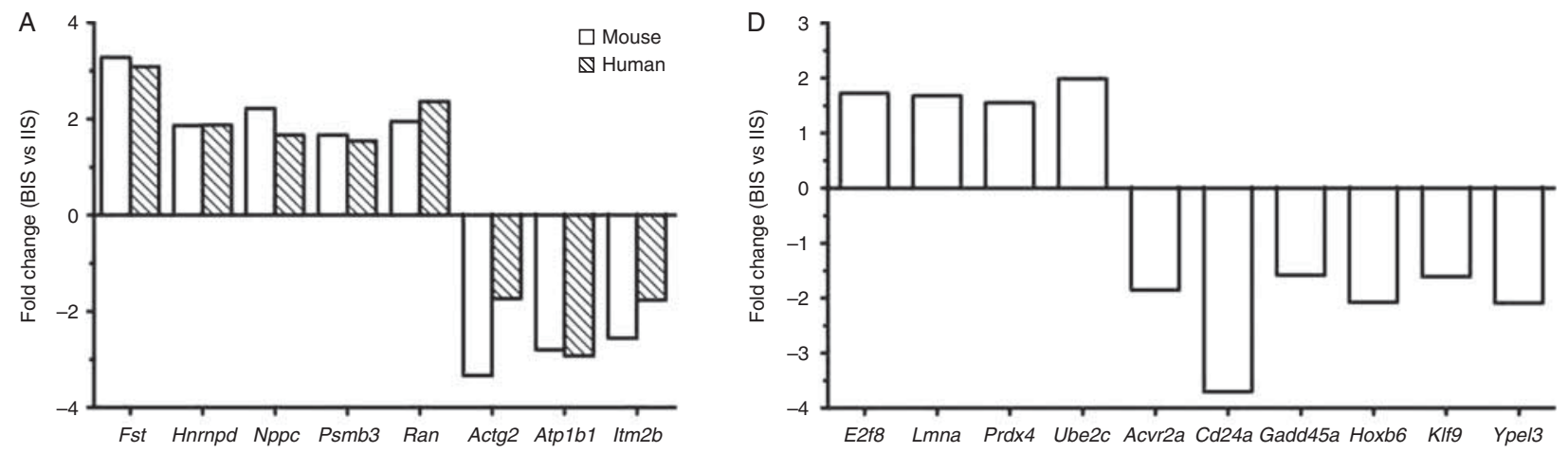

B

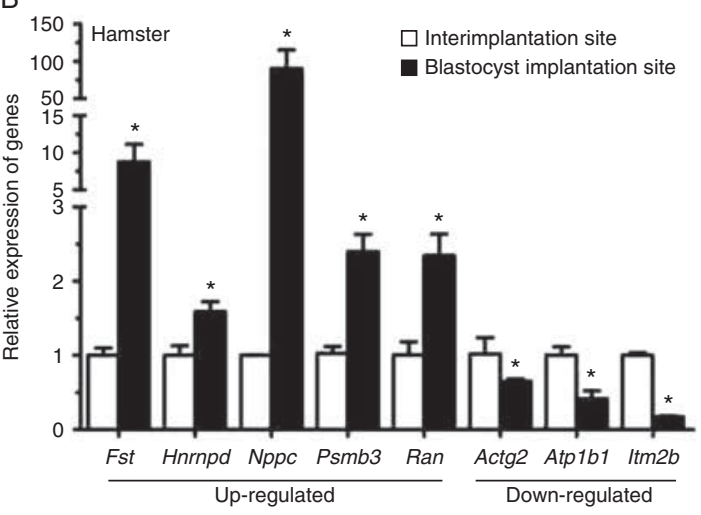

$\mathrm{E}$
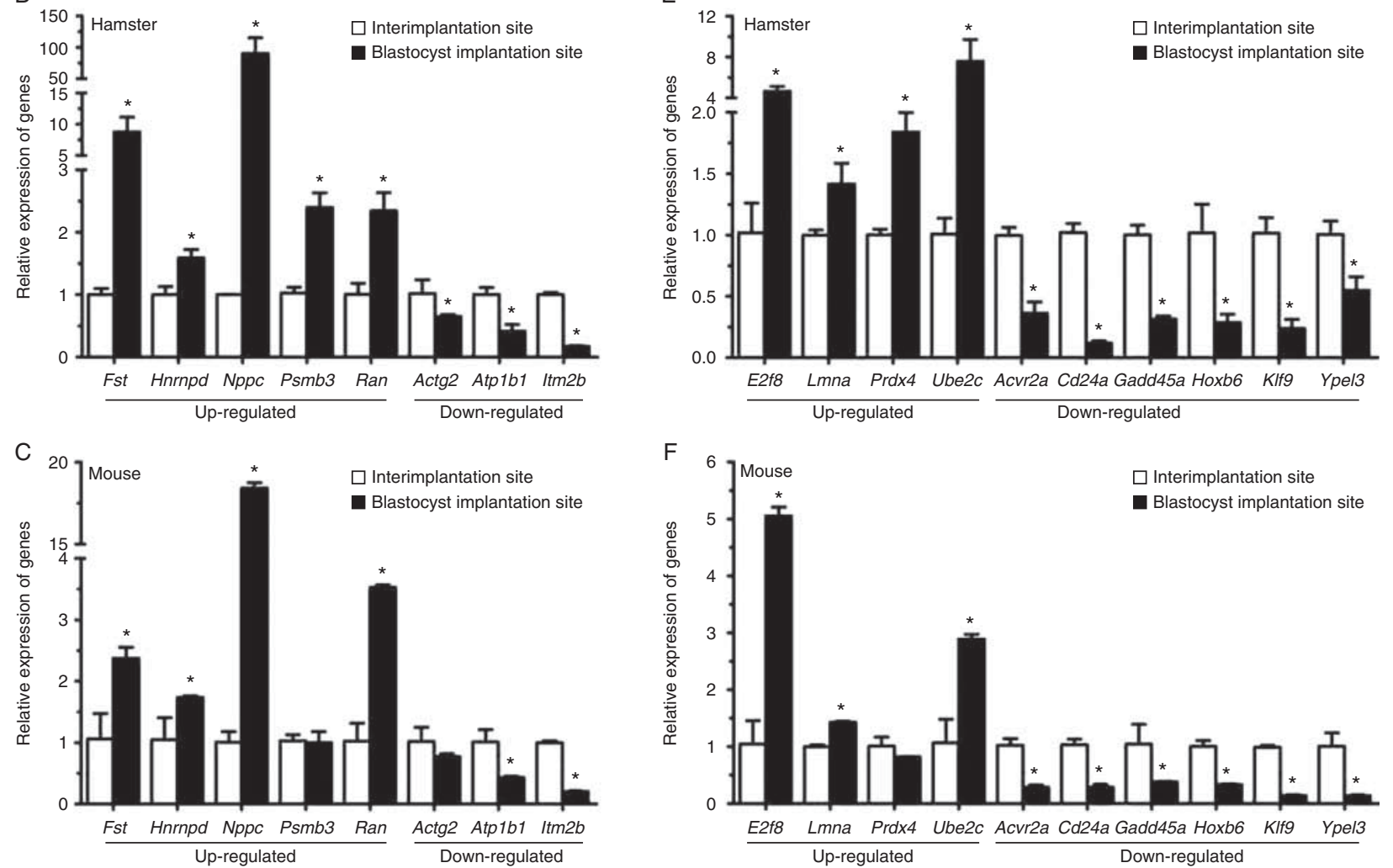

Figure 2 Real-time RT-PCR validated the expression of 18 altered genes relative to the house keeping gene, Hprt. (A, B, C) Gene transcripts that were identified by both mouse and human gene array platforms; (D, E, F) gene transcripts that were identified by either mouse or human gene array platform; . (A and D) fold-change from microarrays; (B and E) real-time RT-PCR analysis of differentially expressed genes in hamsters; (C and F) real-time RT-PCR analysis of differentially expressed genes in mice. Real-time RT-PCR data is shown as mRNA levels in the blastocyst implantation site (black bars) relative to the interimplantation site (white bars). Changes in gene expression were determined in triplicate by real-time PCR. Error bars represent \pm S.D. $(n=3) .{ }^{*} P<0.05$ (student's $t$ test).

(mouse array only), and protein synthesis (human array only). A unique molecular and cellular function was found to be enriched only in IIS compared with BIS: cell cycle (mouse array only), cellular assembly, and organization (human array only).

\section{Biological pathways and processes}

Canonical pathway analysis of both arrays by IPA revealed the most enriched molecular pathways $(-\log (\mathrm{B}-\mathrm{H} P$ value $\geq 1.00)$ at the BIS including protein ubiquitination, hypoxia signaling in the cardiovascular system, aldosterone signaling in epithelial cells, glucocorticoid receptor signaling, aryl hydrocarbon receptor signaling, epithelial adherens junction and gap junction signaling, and RAN signaling pathways (Table 6). Often, individual genes were found in more than one category. As for example, genes associated with the protein ubiquitin pathway were also associated with hypoxia signaling in the cardiovascular system, aldosterone 

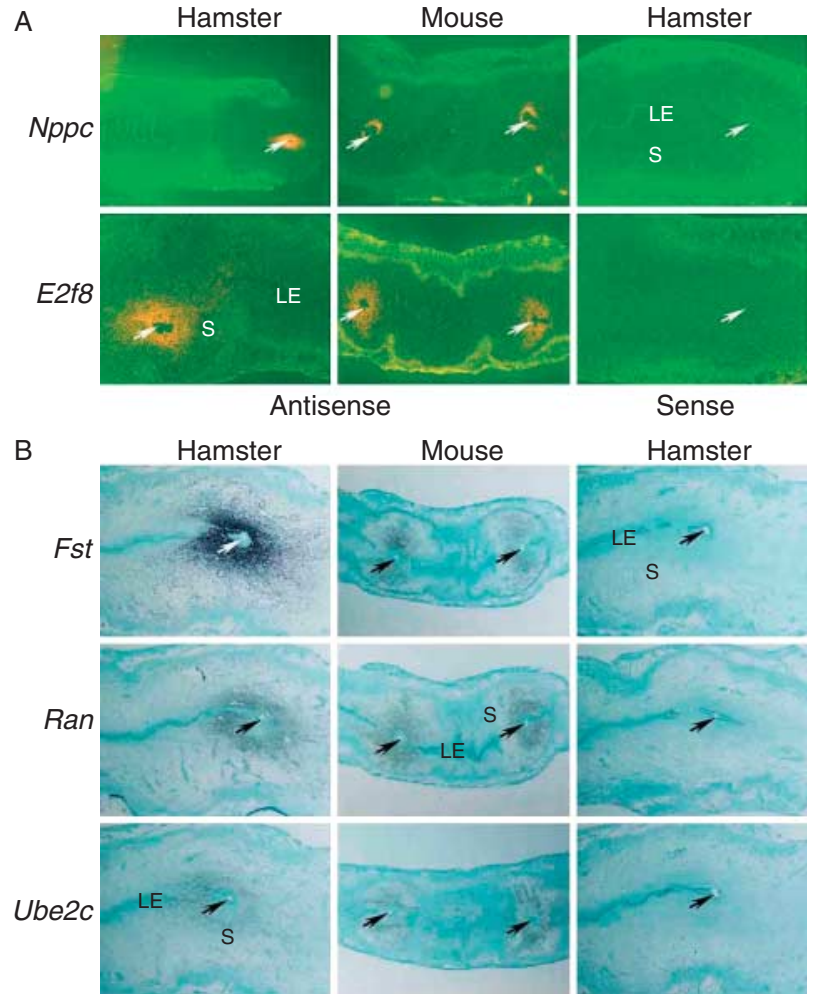

Antisense

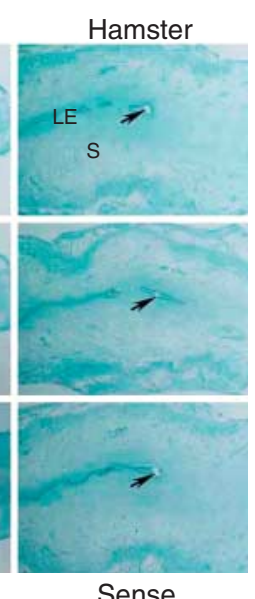

Figure 3 Longitudinal sections of the day 5 blastocyst implantation sites from hamsters and mice were processed for in situ hybridization to demonstrate site and cell-specific expression of differentially expressed genes. (A) Representative dark-field images $(20 \times)$ of three experiments using ${ }^{35}$ S-labled probes. (B) Representative bright-field images $(20 \times)$ of three experiments using digoxigenin-labeled probes. Arrows indicate location of the implanted blastocyst. LE, luminal epithelium; S, stroma

signaling in epithelial cells, and glucocorticoid receptor signaling. Cluster analysis of GO biological processes and KEGG pathway analysis of upregulated genes identified at the BIS by both arrays showed dominance of processes related to splicesome, proteasome, cell cycle, macromolecular and protein complex biogenesis/ assembly, gap junction, pathogenic Escherichia coli infection, cytoskeletal organization, protein localization/transport RNA transport/localization, and mesenchymal development (Table 7). The pathways that were diminished at the BIS included tight junction signaling, SAPK/JNK signaling, PPAR $\alpha / R X R \alpha$ activation and function, and epithelial adherens junction signaling. However, these pathways were only significantly $(-\log$ (B-H $P$ value) $\geq$ to 1.0)) altered using genes provided by the mouse array platform (Table 8 ). Cluster analysis of KEGG pathways and GO biological processes (Table 9) identified regulation of steroid and lipid metabolic processes as the most enriched annotation cluster, which included genes identified as the SAP/JNK pathway using IPA.

\section{Top ranked gene networks}

We next investigated possible gene networks of up- and down-regulated genes identified by both arrays. The top ranked networks included several genes involved in the most enriched molecular and cellular functions and canonical pathways identified by IPA. The top networks constructed by IPA based on the functional and biological connectivity of the 190 genes identified as differentially expressed using the mouse array platform included RNA post-transcriptional modification and molecular transport with a score of 45 and protein synthesis/degradation with a score of 40 (Fig. 4, left panel). Similarly, IPA identified the top networks using the 100 differentially expressed genes at hamster BIS using the human array platform, including cancer and RNA post-transcriptional modification and molecular transport, with scores of 51 and 43 respectively (Fig. 4, right panel). Importantly, the gene network related with RNA post-transcriptional modification and molecular transport was identified by both arrays (Fig. 4).

\section{CSM data identified common altered genes at the BIS of mouse and hamsters}

Genes that are differentially expressed between whole BIS and IIS of mice have been identified using the techniques of RNA differential display (Nie et al. 2000), serial analysis of gene expression (Ma et al. 2006), and cDNA microarray (Reese et al. 2001). Temporal gene expression profile in the luminal epithelial cells of the mouse implantation site was also studied using cDNA

Table 5 Enriched or repressed molecular and cellular functions identified by the ingenuity Pathway Analysis at the hamster blastocyst implantation site (BIS).

\begin{tabular}{|c|c|c|c|}
\hline \multicolumn{2}{|c|}{ Order/platform } & $\begin{array}{l}\text { Molecular and cellular } \\
\text { function }\end{array}$ & B-H $P$ value \\
\hline \multicolumn{4}{|c|}{ Upregulated at BIS } \\
\hline \multirow[t]{2}{*}{1} & Mouse & \multirow{2}{*}{$\begin{array}{l}\text { Cellular growth and } \\
\text { proliferation }\end{array}$} & $5.72 \times 10^{-13}$ \\
\hline & Human & & $1.11 \times 10^{-7}$ \\
\hline \multirow[t]{2}{*}{2} & Mouse & \multirow{2}{*}{$\begin{array}{l}\text { RNA post-transcriptional } \\
\text { modification }\end{array}$} & $1.85 \times 10^{-8}$ \\
\hline & Human & & $7.48 \times 10^{-7}$ \\
\hline 3 & Mouse & \multirow[t]{2}{*}{ Cell death and survival } & $6.02 \times 10^{-8}$ \\
\hline 5 & Human & & $1.96 \times 10^{-5}$ \\
\hline 4 & Mouse & \multirow[t]{2}{*}{ Cellular development } & $1.30 \times 10^{-6}$ \\
\hline 3 & Human & & $2.19 \times 10^{-6}$ \\
\hline 5 & Mouse & \multirow[t]{2}{*}{ Protein synthesis } & $3.78 \times 10^{-6}$ \\
\hline 4 & Human & & $1.48 \times 10^{-5}$ \\
\hline \multicolumn{4}{|c|}{ Downregulated at BIS } \\
\hline \multirow[t]{2}{*}{1} & Mouse & \multirow[t]{2}{*}{ Cell death and survival } & $1.22 \times 10^{-7}$ \\
\hline & Human & & $1.23 \times 10^{-5}$ \\
\hline \multirow[t]{2}{*}{2} & Mouse & \multirow{2}{*}{$\begin{array}{l}\text { Cellular growth and } \\
\text { proliferation }\end{array}$} & $6.75 \times 10^{-5}$ \\
\hline & Human & & $2.27 \times 10^{-4}$ \\
\hline \multirow[t]{2}{*}{3} & Mouse & \multirow{2}{*}{ Cell development } & $5.05 \times 10^{-3}$ \\
\hline & Human & & $1.65 \times 10^{-3}$ \\
\hline 4 & Mouse & $\begin{array}{l}\text { RNA post-transcriptional } \\
\text { modification }\end{array}$ & $6.07 \times 10^{-3}$ \\
\hline 4 & Human & $\begin{array}{l}\text { Cell assembly and } \\
\text { organization }\end{array}$ & $1.80 \times 10^{-3}$ \\
\hline 5 & Mouse & Cell cycle & $6.07 \times 10^{-3}$ \\
\hline 5 & Human & Protein synthesis & $3.69 \times 10^{-3}$ \\
\hline
\end{tabular}


Table 6 Overrepresented canonical pathways at the blastocyst implantation site identified by the Ingenuity Pathway Analysis.

\begin{tabular}{|c|c|c|c|}
\hline Canonical pathway & $-\log (\mathrm{B}-\mathrm{H} P$ value $)$ & Represe & tative genes \\
\hline Protein ubiquitination pathway & 5.49 & M: Hspa4, Hspa5, Psmc4, Ube2c & S: Hsp90aa1, Hsp90b1, Hspd1, Psma7, \\
\hline & 5.02 & $\mathrm{H}:$ Psme3, Ube2m & Psmb3, Psmb7, Psmd1, Ube2s \\
\hline Hypoxia signaling in the & 1.61 & M: Ube2c & S: Hsp90aa1, Hsp90b1, Ube2s \\
\hline cardiovascular system & 2.89 & $\mathrm{H}:$ Ube $2 m$ & \\
\hline $\begin{array}{l}\text { Aldosterone signaling in epithelial } \\
\text { cells }\end{array}$ & $\begin{array}{l}1.21 \\
1.30\end{array}$ & M: Hspa4, Hspa5 & S: Hsp90aa1, Hsp90b1, Hspd1 \\
\hline Glucocorticoid receptor signaling & $\begin{array}{l}1.00 \\
1.35\end{array}$ & $\begin{array}{l}\text { M: Fkbp4, Hspa4, Hspa5 } \\
\text { H: Polr2e }\end{array}$ & S: Hmgb1, Hspa4, Hspa5 \\
\hline Aryl hydrocarbon receptor signaling & $\begin{array}{l}0.93 \\
1.35\end{array}$ & $\begin{array}{l}\text { M: Aldh1a2, Mcm7 } \\
\mathrm{H}: \text { Ccna2 }\end{array}$ & S: Hsp90aa1, Hsp90b1 \\
\hline $\begin{array}{l}\text { Epithelial adherens junction signaling } \\
\text { and gap junction signaling }\end{array}$ & 0.55 & $\begin{array}{l}\text { M: Tuba3a/Tuba3b (Tuba3e), } \\
\text { Tubb5 (Tubb) }\end{array}$ & S: Tubb4b \\
\hline RAN signaling & $\begin{array}{l}2.76 \\
2.11 \\
1.93\end{array}$ & $\begin{array}{l}\text { H: Tubb3, Tuba1a, Tuba1b, Tuba1c } \\
\text { M: Kpnb1, Ranbp1 } \\
\text { H: Хpo1 }\end{array}$ & S: Ran \\
\hline
\end{tabular}

$M$, mouse array; $H$, human array; $S$, shared between mouse and human arrays.

microarray (Chen et al. 2006). The global gene expression profile of human (Kao et al. 2002) and mouse (Xiao et al. 2014) endometrium during the window of implantation has also been investigated. However, to determine whether our cross-species hybridization microarray analyses identified novel transcripts enriched in BIS from hamsters compared with mice, we compared our differentially expressed genes list obtained from each microarray platforms with our previously reported mouse microarray study (Fig. 5A), which is the only study to date examining trancriptomal differences between whole BIS and IIS on day 5 of pregnancy using microarray analysis. We should note that a different Affymetrix GeneChip (U74A) was used for the array study using mouse BIS, compared with the GeneChip U430A used in the present hamster study. Nevertheless, using the same 1.5 -fold, $P<0.05$ cutoff threshold, a total of 124 enhanced transcripts from

Table 7 Enriched biological processes at the blastocyst implantation site identified by DAVID.

\begin{tabular}{|c|c|c|c|c|c|}
\hline \multirow{2}{*}{$\begin{array}{l}\text { DAVID: GO biological } \\
\text { process/KEGG cluster }\end{array}$} & \multirow[b]{2}{*}{ AC no. } & \multirow[b]{2}{*}{ ES } & \multirow{2}{*}{$\begin{array}{c}\text { Benjamini } \\
P \text { value }\end{array}$} & \multicolumn{2}{|c|}{ Representative genes } \\
\hline & & & & Mouse/human array & Shared $^{\mathrm{a}}$ array \\
\hline \multirow[t]{2}{*}{$\begin{array}{l}\text { RNA processing/splicing, } \\
\text { splicesome }\end{array}$} & 1 & 3.97 & $1.70 \times 10^{-2}$ & $\begin{array}{l}\text { M: Hnrnpu, Nhp2, Pabpn2, Pa2g4, } \\
\text { Ppih, Snrpa, Snrpa1, Sfpq, Snrpd2, } \\
\text { Tra2b, Wdr12 }\end{array}$ & $\begin{array}{l}\text { Hnrnpa2b1, Hnrnpa3, Hnrnpd, } \\
\quad \text { Syncrip }\end{array}$ \\
\hline & 4 & 2.37 & $1.50 \times 10^{-2}$ & H: Gspt1, Polr2e, Prmt5, Tardbp1, Wt1 & \\
\hline $\begin{array}{l}\text { Cell cycle, proteosome, } \\
\text { ubiquitin-mediated } \\
\text { proteolysis }\end{array}$ & 1 & 3.09 & $2.30 \times 10^{-4}$ & $\begin{array}{l}\text { H: Ccna2, Eif4g2, Eif5a, Fst, Gspt1, } \\
\text { Hmgb1, Hnrnpab, Hnrnpd, Hspd1, } \\
\text { Nppc, Psme3, Ran, Sssca1, Tardbp, } \\
\text { Tubb3, Ube2m, Wt1, Ywhae }\end{array}$ & $\begin{array}{l}\text { Hsp90b1, Psma7, Psmb3, Psmb7, } \\
\text { Psmd1, Ube2s }\end{array}$ \\
\hline $\begin{array}{l}\text { Proteosome/ubiquitin-mediated } \\
\text { proteolysis }\end{array}$ & 7 & 1.29 & $1.20 \times 10^{-2}$ & $\begin{array}{l}\text { M: Pcolce, Psmc4, Psmd1, Ube2c, } \\
\quad \text { Ube } 2 k, \text { Vcp }\end{array}$ & $\begin{array}{l}\text { Hsp90b1, Psma7, Psmb3, Psmb7, } \\
\text { Psmd1, Ube2s }\end{array}$ \\
\hline \multirow[t]{2}{*}{ Cell cycle } & 2 & 2.99 & $8.00 \times 10^{-5}$ & $\begin{array}{l}\mathrm{H}: \text { Ccna2, Eif4g2, Fzd2, Gspt1, Nasp, } \\
\text { Ppm1g, Psmd1, Psme3, Sssca1, } \\
\text { Tardbp, Tubb3, Ywhag }\end{array}$ & Cks2, Ran \\
\hline & 6 & 1.29 & $3.10 \times 10^{-1}$ & $\begin{array}{l}\text { M: Anp32b, E2f8, Khdrbs1, Mcm5, } \\
\text { Mcm7, Nudc, Ranbp1, Spag5, } \\
\text { Tubb5, Ube2c }\end{array}$ & \\
\hline $\begin{array}{l}\text { Macromolecular and protein } \\
\text { complex biogenesis/assembly, } \\
\text { Gap Junction, pathogenic } \\
\text { Escherichia coli infection }\end{array}$ & 3 & 2.55 & $7.30 \times 10^{-3}$ & $\begin{array}{l}\text { H: Cks2, Hsp90aa1, Hspd1, Mif, Nasp, } \\
\text { Polr2e, Prmt5, Ran, Tuba1b, Tuba1c, } \\
\text { Tubb3, Xpo1 }\end{array}$ & H2afz \\
\hline $\begin{array}{l}\text { Macromolecular and protein } \\
\text { complex biogenesis/assembly }\end{array}$ & 2 & 2.29 & $1.20 \times 10^{-1}$ & $\begin{array}{l}\text { M: Calr, Eif6, Fkbp4, Kpnb1, Rrm1, Set, } \\
\text { Tuba3a, Tubb5 }\end{array}$ & H2afz \\
\hline Cytoskeletal organization & 6 & 1.15 & & $\begin{array}{l}\mathrm{H}: \text { Cks2, Ran, Tmsb10, Tuba1b, } \\
\quad \text { Tuba1c, Tubb3 }\end{array}$ & \\
\hline \multirow[t]{2}{*}{ Protein localization/transport } & 3 & 1.98 & $2.30 \times 10^{-1}$ & $\begin{array}{l}\text { M: Kpnb1, Nop58, Nutf2, Pcna, } \\
\text { Ranbp1, Rrbp1, Tomm40, Vcp }\end{array}$ & Eif5a, Ran, Tmsb10, Ywhag \\
\hline & 5 & 1.42 & $4.60 \times 10^{-2}$ & $\begin{array}{l}\mathrm{H}: \text { Atp2a2, Hnrnpa2b1, Hsp90aa1, } \\
\text { Hsp90b1, Nasp, Хpo1 }\end{array}$ & \\
\hline RNA transport/localization & 4 & 1.78 & $3.30 \times 10^{-1}$ & M: Eif5a, Eny2, G3bp2, Hnrnpa2b1 & \\
\hline Mesenchyme development & 5 & 1.33 & $6.00 \times 10^{-1}$ & M: Aldh1a2, Hnrnpab, Trim28 & \\
\hline
\end{tabular}

$A C$, annotation cluster; $E S$, enrichment score $(\geq 1, P<0.05)$ provided by DAVID bioinformatics database; $M$, mouse array; $H$, human array. ${ }^{a}$ Shared between mouse and human arrays. 
Table 8 Underrepresented canonical pathways at the blastocyst implantation site identified by the ingenuity pathway analysis.

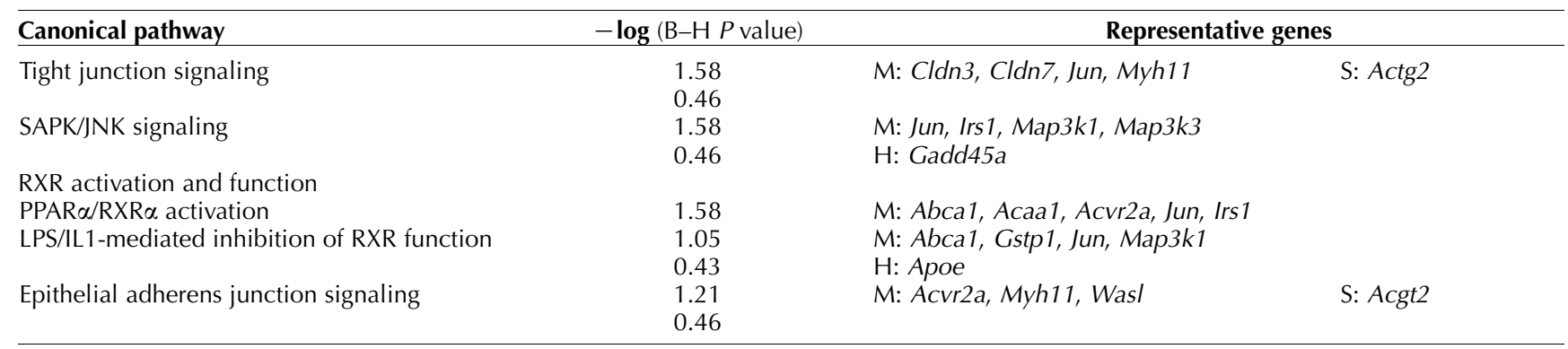

M, mouse array; $\mathrm{H}$, Human array; S, Shared between mouse and human arrays.

mouse BIS were compared with our 174 enhanced transcripts from hamster BIS. There were a total of 19 genes that were similarly upregulated in BIS from mice and hamsters on day 5 of pregnancy, listed in Fig. 5A. Of these 19 genes, four were similarly identified as upregulated in hamster BIS using both microarray platforms: follistatin (Fst), heat shock protein 90, $\alpha$ (cytosolic), class A member 1 (Hsp90aa1), heterogeneous nuclear riboprotein D (Hnrnpd) and serine/ arginine-rich splicing factor 2 (Srsf2). When compared with the 115 genes found to be downregulated in hamster BIS using our cross-hybridization arrays, we found only eight genes that were similarly downregulated in mice BIS, out of 110 from our previously mouse study (Fig. 5B). Of these eight genes, remarkably only one gene was identified as downregulated in hamster BIS by both array platforms: lysine (K)-specific demethylase 6A (Kdm6a).

\section{Discussion}

Blastocyst implantation is a complex uterine site-specific process that is a crucial event of mammalian pregnancy. It is possible that this event is regulated by an

Table 9 Diminished biological processes at the blastocyst implantation site identified by DAVID.

\begin{tabular}{|c|c|c|c|c|c|}
\hline \multirow{2}{*}{$\begin{array}{l}\text { DAVID: GO biological process/ } \\
\text { KEGG cluster }\end{array}$} & \multirow[b]{2}{*}{ AC no. } & \multirow[b]{2}{*}{ ES } & \multirow[b]{2}{*}{ FDR } & \multicolumn{2}{|l|}{ Representative genes } \\
\hline & & & & Mouse/human array & Shared $^{\mathrm{a}}$ array \\
\hline $\begin{array}{l}\text { Regulation of steroid and lipid } \\
\text { metabolic processes }\end{array}$ & 1 & 1.95 & $4.40 \times 10^{-1}$ & $\mathrm{H}:$ Apoe, Glul, Igfbp7, Kcnma1 & Hspb1, Pdgfra \\
\hline $\begin{array}{l}\text { Response to peptide hormone stimulus } \\
\text { and organic substance }\end{array}$ & 6 & 1.11 & $7.00 \times 10^{-1}$ & $\begin{array}{l}\text { M: App, Btg2, Irs1, Jun, Kdm3a, Map3k1, } \\
\quad \text { Mcl, Ube } 2 b\end{array}$ & \\
\hline $\begin{array}{l}\text { Response to steroid hormone stimulus } \\
\text { and organic substance }\end{array}$ & 8 & 1.06 & $6.40 \times 10^{-1}$ & $\mathrm{H}:$ Apoe, Glul, Igfbp7, Kcnma1 & \\
\hline $\begin{array}{l}\text { Regulation of cell proliferation and } \\
\text { growth }\end{array}$ & 2 & 1.93 & $5.20 \times 10^{-1}$ & $\begin{array}{l}\mathrm{H}: \text { Apoe, Bcl6, Btg1, Igfbp7, Jag1, NfIB, } \\
\quad \text { Pdgfra }\end{array}$ & \\
\hline $\begin{array}{l}\text { Regulation of cell proliferation/ } \\
\text { migration, cell surface receptor } \\
\text { linked signal transduction }\end{array}$ & 6 & 1.35 & $5.50 \times 10^{-1}$ & $\begin{array}{l}\mathrm{H}: \text { Apoe, Bcl6, Btg1, Igfbp7, Jag1, NfIB, } \\
\quad \text { Pdgfra, Sptbn1 }\end{array}$ & \\
\hline Phosphorylation & 1 & 1.78 & $3.60 \times 10^{-1}$ & $\begin{array}{c}\text { M: Acvr2a, App, Atp6v0b, Clk1, Clk4, } \\
\text { Enpp2, Map3k1, Map3k3, Pdgfra }\end{array}$ & \\
\hline $\begin{array}{l}\text { Posttranscriptional regulation of } \\
\text { gene expression }\end{array}$ & 3 & 1.44 & $6.80 \times 10^{-1}$ & $\begin{array}{l}\text { M: Acvr2a, App, Eif4a2, Hspb1, Jun, } \\
\quad \text { Map3k1, Ube2b, Zfp36I2 }\end{array}$ & \\
\hline \multirow[t]{2}{*}{ Regulation of apoptosis/cell death } & 3 & 1.85 & $3.70 \times 10^{-1}$ & $\begin{array}{l}\mathrm{H}: \text { Apoe, Bcl6, Btg1, Cadm1, Hoxb6, } \\
\text { Kcnma1, Son }\end{array}$ & Hspb1, Itm2b \\
\hline & 7 & 1.06 & $4.30 \times 10^{-1}$ & $\begin{array}{l}\text { M: Abca1, Acvr2a, App, Atp1a2, Btg2, } \\
\text { Ccnl2, Dlx5, Eif4a2, Enpp2, Gstp1, } \\
\text { Hoxb8, Irs1, Jun, Kdm3a, Klf9, Map3k1, } \\
\text { Map3k3, Mcl1, Pdgfra, Rbm39, } \\
\text { S100a6Serinc3, Sgms1, Suv420h1, } \\
\text { Ube2b, Wasl, Zbtb16, Zfp36l2 }\end{array}$ & \\
\hline $\begin{array}{l}\text { Circulatory/vascular system } \\
\text { process }\end{array}$ & 4 & 1.79 & $5.80 \times 10^{-1}$ & $\mathrm{H}:$ Actg2, Apoe, Kcnma1 & \\
\hline Blood vessel/ vasculature development & 9 & 1.02 & $7.20 \times 10^{1}$ & $\mathrm{H}:$ Apoe, Jag1, Sox17 & \\
\hline Response to abiotic stimulus & 4 & 1.37 & $5.40 \times 10^{-1}$ & $\begin{array}{l}\text { M: App, Atp1a2, Btg2, Hspb1, Jun, } \\
\text { Map3k1, Ube2b }\end{array}$ & \\
\hline Ear development & 5 & 1.55 & $6.30 \times 10^{-1}$ & $\mathrm{H}:$ Jag1, Kcnma1, Pdgfra & \\
\hline $\begin{array}{l}\text { Anterior/posterior pattern formation, } \\
\text { embryonic morphogenesis }\end{array}$ & 2 & 1.46 & $4.40 \times 10^{-1}$ & $\begin{array}{l}\text { M: Acvr2a, Btg2, Dlx5, Hoxb8, Pdgfra, } \\
\quad \text { Zbtb16 }\end{array}$ & \\
\hline
\end{tabular}

AC, annotation cluster; ES, enrichment score $(\geq 1, P<0.05)$ provided by DAVID bioinformatics database. $M$, mouse array; $H$, human array.

${ }^{\text {a }}$ Shared between mouse and human arrays. 


\section{Mouse}

Human

\section{RNA post-transcriptional modification and transport}

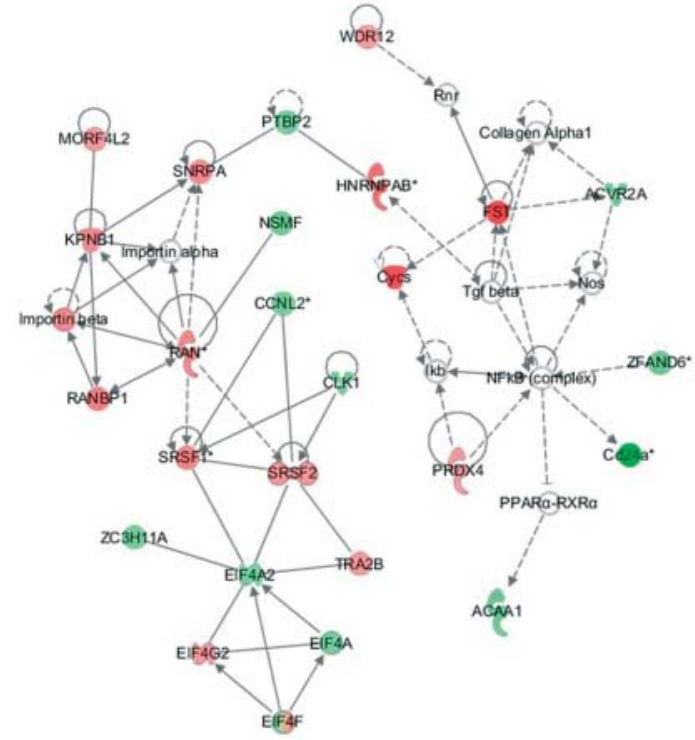

Protein Synthesis/Degradation

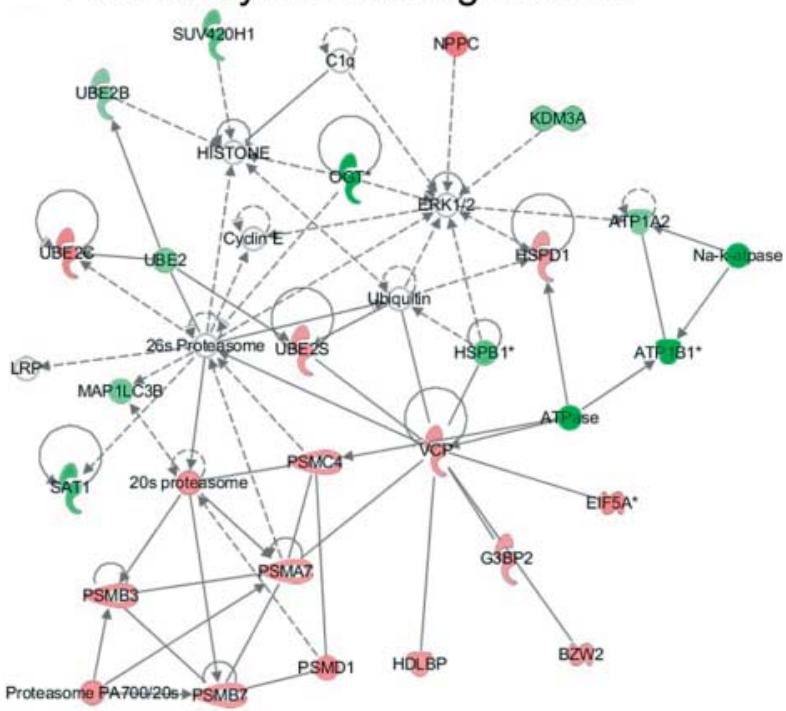

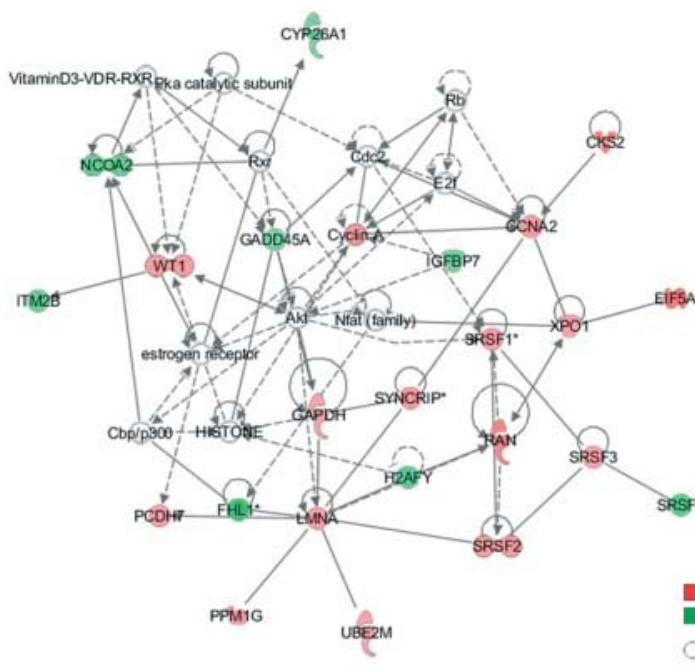

Induced genes Repressed genes Complex Enzyme Group/Complex/Other Kinase Peptidase Phosphatase Transcription Regulato Translation Regulator Transporter Unknown Unknown

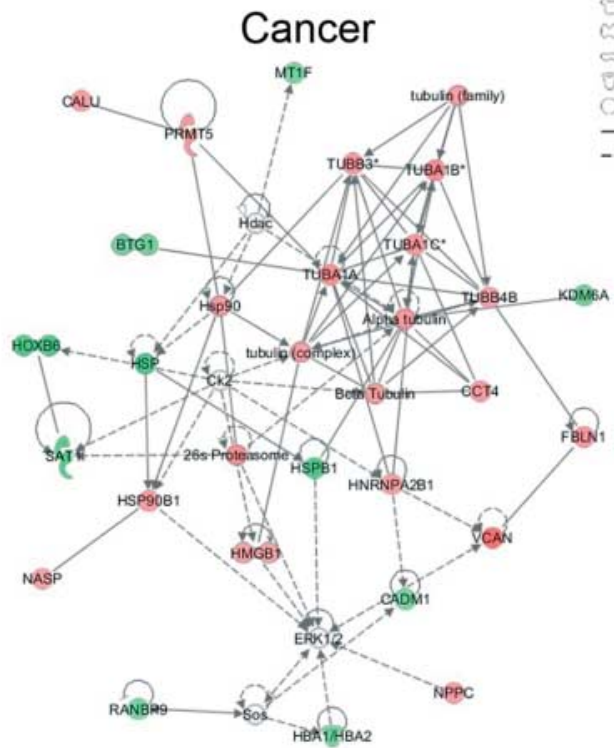

Figure 4 Most significant gene networks of differentially expressed genes at the blastocyst implantation site of the hamster. IPA constructed the top biological networks enriched and repressed at BIS based on the functional and biological connectivity of the 190 and 100 genes identified using mouse and human $\mathrm{CSH}$ arrays respectively. The top two networks are shown, and are graphically represented as nodes (genes) and edges (biological relationship between genes). Red and green colors represent induced or repressed genes, respectively, while clear nodes are those that IPA included based on the relationship. Color gradations are based upon gene regulation at the fold-change level.

evolutionarily common genetic pool with conserved functions across species. However, given the variation in the mode and ovarian steroid hormonal regulation of blastocyst implantation among species (Reese et al. 2008), genetic profiling of the BISs of various species may become useful for the identification of a separate gene pool that differs between the $\mathrm{P}_{4}$-dependent and the $\mathrm{P}_{4}$ plus E-dependent implantation process. This study unveils for the first time a differentially expressed gene profile at the BIS of hamsters using CSM techniques, and demonstrates putative biological processes/pathways/ gene networks that may contribute to the process of implantation in general and/or ovarian $\mathrm{P}_{4}$-dependent implantation process in hamsters.

Both array platforms yielded a relatively small number of differentially expressed genes at the hamster BIS. This finding is somewhat unexpected, but is quite explicable by the fact that most CSM probes identify genes that 
A

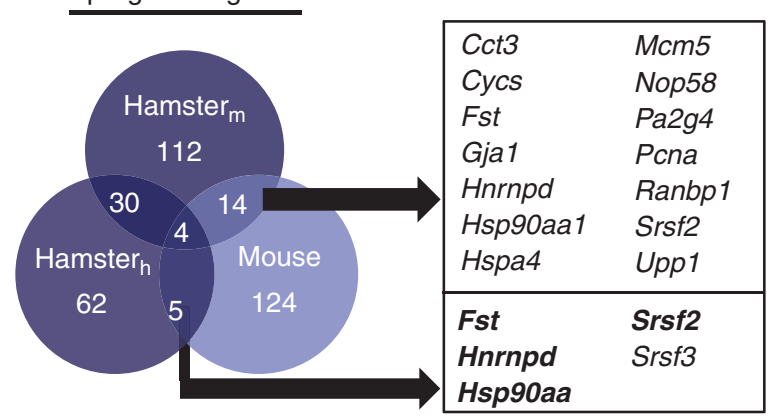

B

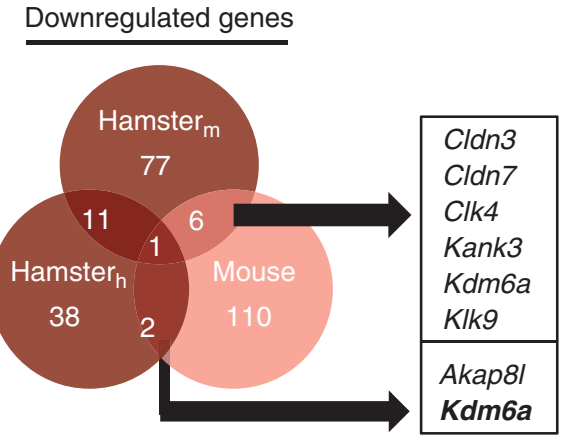

Figure 5 Comparison of the hamster cross-species microarray data with the mouse microarray data revealed a subset of conserved genes at the blastocyst implantation sites of the mouse and hamster. Hamster crossspecies hybridization microarray data from this study (mouse

(Hamster ${ }_{m}$ )and human (Hamster $\left.{ }_{h}\right)$ ) was compared with our previously reported mouse microarray experiment comparing BIS with IIS on day 5 of pregnancy. Our differential gene set was compared with the previously microarray using similar parameters $(1.5$-fold, $P<0.05)$. The number of shared genes between these two microarray studies is stated in the Venn diagram, for both the upregulated and downregulated data sets. Symbols for the shared genes are provided in the boxes. Genes that were validated by real-time PCR are in boldface.

show high sequence conservation. In spite of this limitation, PCA and hierarchial heat-map clustering of differentially expressed probes and genes revealed two distinctive transcriptomes in uterine sites with or without the implanted blastocyst, indicating that the gene signature at the BIS is distinct from the IIS. Furthermore, correlation between the microarray data and the real-time PCR results verified the trends (up- or down-regulation) of 18 differentially expressed genes (unshared or shared) at various levels (higher- or smallerfold difference) at the hamster BIS, clearly confirming that genes identified by both arrays are not an artifact and may represent the uterine functional state. We noted some quantitative differences between array results and real-time RT-PCR based data. We assume that this variation is likely based on the greater technological sensitivity of the latter. This interpretation is also supported by our in situ hybridization method (a secondary procedure used to validate our microarray as well as real-time PCR results) that demonstrated strong accumulation of mRNAs of five upregulated genes at the BIS compared with the IIS. Taken together, our findings indicate the qualitative accuracy of our cross-species array results and reliably identified transcripts having higher or smaller differences in expression between RNA samples from BIS and IIS. To our knowledge, there is no published manuscript comparing the uterine gene expression profile of the hamster BIS and IIS using microarray analysis. Therefore, we believe that we have identified a group of genes that perhaps can be used to define up- or down-regulated molecular signaling in the hamster BIS. Among these genes, those that failed to show differential expression in the mouse BIS, such as Psmb3, Actg2, and Prdx4, perhaps represent specificity to the hamster BIS. Future studies focusing on these genes may provide insights into the cellular basis of $\mathrm{P}_{4}$-dependent implantation.

Uterine stromal proliferation, differentiation, and cell death must be coordinately executed at the BIS to establish the physiological state of pregnancy following blastocyst implantation. This study successfully identified a considerable number of differentially expressed genes that are involved in regulating the processes and/or pathways of RNA splicing and transport, protein synthesis and degradation, cell proliferation, differentiation, growth, and death. Interestingly, our microarray results also revealed that RNA-post transcriptional modification, protein synthesis and degradation, and cancer are the top biological networks at the BIS. This is not surprising given the enhanced cellular growth and constant remodeling observed at the BIS (Alexander et al. 1996). Moreover, the process of decidualization at BISs is also considered an inflammatory event (Mor et al. 2011), which is a widely accepted component of tumor development and progression (Coussens \& Werb 2002). In general, a cell's adaptation to new physiological conditions in all tissues depends on degradation of specific proteins and RNA synthesis, processing, and transport of new protein synthesis. Thus, analysis of the spliceosome, proteasome, and cancer gene networks at the BIS may be useful for better understanding of how the blastocyst influences uterine growth and remodeling at the site of implantation.

Collectively, this study identified a pool of differentially expressed genes and their possible relationship with cellular and molecular processes or pathways in the hamster BIS. After validation of expression of several of these genes and functional annotation of differentially expressed genes, we speculate that determining the role of these genes at the implantation site will greatly aid in improving our understanding of the molecular mechanisms of blastocyst implantation in general as well as $\mathrm{P}_{4}$-dependent blastocyst implantation. Future RNA-Seq studies comparing the hamster BIS and IIS will be useful for validation of our CSM results, as well as for uncovering any unidentified differentially expressed transcripts, which may differ in nucleotide sequences 
compared with that of respective mouse and/or human. Recently, researchers from the Broad Institute of MIT and Harvard have succeeded in sequencing the genome of the Syrian hamster, and deposited the data online (GenBank: APMT 00000000.1) for public access. This genetic data will be precious for transcript identification in our future RNA-Seq approach toward a better understanding of the molecular pathways associated with blastocyst implantation in hamsters.

\section{Supplementary data}

This is linked to the online version of the paper at http://dx.doi. org/10.1530/REP-14-0388.

\section{Declaration of interest}

The authors declare that there is no conflict of interest that could be perceived as prejudicing the impartiality of the research reported.

\section{Funding}

This work was supported by National Institutes of Health grant HD044741.

\section{Acknowledgements}

The authors acknowledge the technical support provided by Heidi Nguyen.

\section{References}

Alexander CM, Hansell EJ, Behrendtsen O, Flannery ML, Kishnani NS, Hawkes SP \& Werb Z 1996 Expression and function of matrix metalloproteinases and their inhibitors at the maternal-embryonic boundary during mouse embryo implantation. Development 122 1723-1736.

Aplin JD 1991 Implantation, trophoblast differentiation and haemochorial placentation: mechanistic evidence in vivo and in vitro. Journal of Cell Science 99 681-692.

Becker J, Hackl M, Rupp O, Jakobi T, Schneider J, Szczepanowski R, Bekel T, Borth N, Goesmann A, Grillari J et al. 2011 Unraveling the Chinese hamster ovary cell line transcriptome by next-generation sequencing. Journal of Biotechnology 156 227-235. (doi:10.1016/ j.jbiotec.2011.09.014)

Bolstad BM, Irizarry RA, Astrand M \& Speed TP 2003 A comparison of normalization methods for high density oligonucleotide array data based on variance and bias. Bioinformatics 19 185-193. (doi:10.1093/ bioinformatics/19.2.185)

Chen Y, Ni H, Ma XH, Hu SJ, Luan LM, Ren G, Zhao YC, Li SJ, Diao HL, Xu X et al. $2006 \mathrm{Global}$ analysis of differential luminal epithelial gene expression at mouse implantation sites. Journal of Molecular Endocrinology 37 147-161. (doi:10.1677/jme.1.02009)

Coussens LM \& Werb Z 2002 Inflammation and cancer. Nature 420 860-867. (doi:10.1038/nature01322)

DeSouza MM, Surveyor GA, Price RE, Julian J, Kardon R, Zhou X, Gendler S, Hilkens J \& Carson DD 1999 MUC1/episialin: a critical barrier in the female reproductive tract. Journal of Reproductive Immunology 45 127-158. (doi:10.1016/S0165-0378(99)00046-7)
Hammond S, Kaplarevic M, Borth N, Betenbaugh MJ \& Lee KH 2012 Chinese hamster genome database: an online resource for the $\mathrm{CHO}$ community at www.CHOgenome.org. Biotechnology and Bioengineering 109 1353-1356. (doi:10.1002/bit.24374)

Hey NA, Li TC, Devine PL, Graham RA, Saravelos H \& Aplin JD 1995 MUC1 in secretory phase endometrium: expression in precisely dated biopsies and flushings from normal and recurrent miscarriage patients. Human Reproduction 10 2655-2662.

Irizarry RA, Bolstad BM, Collin F, Cope LM, Hobbs B \& Speed TP 2003 Summaries of Affymetrix GeneChip probe level data. Nucleic Acids Research 31 e15. (doi:10.1093/nar/gng015)

Kao LC, Tulac S, Lobo S, Imani B, Yang JP, Germeyer A, Osteen K, Taylor RN, Lessey BA \& Giudice LC 2002 Global gene profiling in human endometrium during the window of implantation. Endocrinology 143 2119-2138. (doi:10.1210/endo.143.6.8885)

Lee KY \& DeMayo FJ 2004 Animal models of implantation. Reproduction 128 679-695. (doi:10.1530/rep.1.00340)

Lei W, Feng XH, Deng WB, Ni H, Zhang ZR, Jia B, Yang XL, Wang TS, Liu JL, Su RW et al. 2012 Progesterone and DNA damage encourage uterine cell proliferation and decidualization through up-regulating ribonucleotide reductase 2 expression during early pregnancy in mice. Journal of Biological Chemistry 287 15174-15192. (doi:10.1074/jbc.M111.308023)

Lei W, Nguyen H, Brown N, Ni H, Kiffer-Moreira T, Reese J, Millan JL \& Paria BC 2013 Alkaline phosphatases contribute to uterine receptivity, implantation, decidualization, and defense against bacterial endotoxin in hamsters. Reproduction 146 419-432. (doi:10.1530/REP-13-0153)

Ma XH, Hu SJ, Ni H, Zhao YC, Tian Z, Liu JL, Ren G, Liang XH, Yu H, Wan P et al. 2006 Serial analysis of gene expression in mouse uterus at the implantation site. Journal of Biological Chemistry 281 9351-9360. (doi:10.1074/jbc.M511512200)

Mor G, Cardenas I, Abrahams V \& Guller S 2011 Inflammation and pregnancy: the role of the immune system at the implantation site. Annals of the New York Academy of Sciences 1221 80-87. (doi:10.1111/ j.1749-6632.2010.05938.x)

Nie GY, Li Y, Batten L, Griffiths B, Wang J, Findlay JK \& Salamonsen LA 2000 Uterine expression of alternatively spliced mRNAs of mouse splicing factor SC35 during early pregnancy. Molecular Human Reproduction 6 1131-1139. (doi:10.1093/molehr/6.12.1131)

Paria BC, Huet-Hudson YM \& Dey SK 1993 Blastocyst's state of activity determines the "window" of implantation in the receptive mouse uterus. PNAS 90 10159-10162. (doi:10.1073/pnas.90.21.10159)

Parkening TA 1976a An ultrastructural study of implantation in the golden hamster. II. Trophoblastic invasion and removal of the uterine epithelium. Journal of Anatomy 122 211-230.

Parkening TA $1976 b$ An ultrastructural study of implantation in the golden hamster. III. Initial formation and differentiation of decidual cells. Journal of Anatomy 122 485-498.

Reese J, Das SK, Paria BC, Lim H, Song H, Matsumoto H, Knudtson KL, DuBois RN \& Dey SK 2001 Global gene expression analysis to identify molecular markers of uterine receptivity and embryo implantation. Journal of Biological Chemistry 276 44137-44145. (doi:10.1074/jbc. M107563200)

Reese J, Wang H, Ding T \& Paria BC 2008 The hamster as a model for embryo implantation: insights into a multifaceted process. Seminars in Cell and Developmental Biology 19 194-203. (doi:10.1016/j.semcdb.2007.11.001)

Rupp O, Becker J, Brinkrolf K, Timmermann C, Borth N, Puhler A, Noll T \& Goesmann A 2014 Construction of a public CHO cell line transcript database using versatile bioinformatics analysis pipelines. PLOS ONE 9 e85568. (doi:10.1371/journal.pone.0085568)

Schmucki R, Berrera M, Kung E, Lee S, Thasler WE, Gruner S, Ebeling M \& Certa U 2013 High throughput transcriptome analysis of lipid metabolism in Syrian hamster liver in absence of an annotated genome. BMC Genomics 14 237. (doi:10.1186/1471-2164-14-237)

Wang X, Su Y, Deb K, Raposo M, Morrow JD, Reese J \& Paria BC 2004 Prostaglandin $E_{2}$ is a product of induced prostaglandin-endoperoxide synthase 2 and microsomal-type prostaglandin $E$ synthase at the implantation site of the hamster. Journal of Biological Chemistry 279 30579-30587. (doi:10.1074/jbc.M400573200)

Wang H, Luan L, Ding T, Brown N, Reese J \& Paria BC 2011 Dynamics of zonula occludens-2 expression during preimplantation embryonic development in the hamster. Theriogenology 76 678-686. (doi:10. 1016/j.theriogenology.2011.03.021) 
WARD MC 1948 The early development and implantation of the golden hamster, Cricetus auratus, and the associated endometrial changes. American Journal of Anatomy 82 231-275. (doi:10.1002/aja. 1000820204)

Xiao S, Diao H, Zhao F, Li R, He N \& Ye X 2014 Differential gene expression profiling of mouse uterine luminal epithelium during periimplantation. Reproductive Sciences 21 351-362. (doi:10.1177/1933719113497287)

Xu X, Nagarajan H, Lewis NE, Pan S, Cai Z, Liu X, Chen W, Xie M, Wang W, Hammond S et al. 2011 The genomic sequence of the Chinese hamster ovary (CHO)-K1 cell line. Nature Biotechnology 29 735-741. (doi:10.1038/nbt.1932)
Zhang Q \& Paria BC 2006 Importance of uterine cell death, renewal, and their hormonal regulation in hamsters that show progesterone-dependent implantation. Endocrinology 147 2215-2227. (doi:10.1210/en.20051555)

Received 31 July 2014

First decision 19 August 2014

Revised manuscript received 4 September 2014

Accepted 23 September 2014 